\title{
THE PROPOSED YUCCA MOUNTAIN REPOSITORY FROM A CORROSION PERSPECTIVE
}

\author{
Joe H. Payer \\ Case Westem Reserve University
}

Corrosion is a primary determinant of waste package performance at the proposed Yucca Mountain Repository and will control the delay time for radionuclide transport from the waste package. Corrosion is the most probable and most likely degradation process that will determine when packages will be penetrated and the shape size and distribution of those penetrations. The general issues in corrosion science, materials science and electrochemistry are well defined, and the knowledge base is substantial for understanding corrosion processes. In this paper, the Yucca Mountain Repository is viewed from a corrosion perspective.

Corrosion resistance of the waste package outer canister

A major component of the long-term strategy for safe disposal of nuclear waste at the proposed Yucca Mountain Repository is first to completely isolate the radionuclides in the waste packages for long times and to greatly retard the egress and transport of radionuclides from penetrated packages. Highly corrosion resistant metals are selected for the waste packages and drip shields of the Yucca Mountain Repository: Alloy 22, a nickelchromium-molybdenum alloy and titanium, respectively. Both Alloy 22 and titanium have high corrosion resistance in the oxidizing environments of interest for the proposed Yucca Mountain Repository.

Alloy 22 is a member of a corrosion resistant family of alloys that were developed for highly aggressive, oxidizing acid applications. These alloys and titanium are at the topof-the-list for corrosion resistance. Comparative results from accelerated laboratory tests and examples of industrial applicetions are presented. The passive corrosion rates of Alloy 22 and titanium are measured at 0.1 to 0.01 um/yr. Based on these rates, the penetration of one millimeter of the passive metals would take 16,000 to 160,000 years. Therefore, passive metals that remain passive can provide extremely long sevice lives.

A framework for the analysis of localized corrosion processes

The Yucca Mountain Repository presents a common materials performance application that is encountered in energy, transportation and other industries. The widely accepted approach to dealing with materials performance is to identify the performance requirements, to determine the operating conditions that materials will be exposed to and to select materials of construction that perform well in those conditions. A special feature of Yucca Mountain is the extremely long time frame of interest, i.e. 10,000's of years and longer. Thus, the time evolution of the environment in contact with waste package surfaces and the time evolution of corrosion damage that may result are of primary interest in the determination of expected performance. 
Since no material is immune to all environmental conditions, an approach is to specify a material with sufficient corrosion resistance over the range of expected environments. The objective is to determine the corrosion behavior over a broad range of environments that cover the expected conditions. Thermal-hydrological-chemical models and experiments determine the water chemistry and temperature ranges of interest The waters can be placed into categories of waters of relevance to corrosion behavior, e.g. carbonate waters, sodium-potassium chloride-nitrate waters, and calcium-magnesium chloride-nitrate waters.

The corrosion resistance is determined by long-term exposure of metal specimens and widely accepted electrochemical tests. For example, fonvard-reverse polarization tests on specimens under fully irnmersed conditions with severe crevice formers determine the localized corrosion behavior as a function of solution composition, acidity $(\mathrm{pH})$ and temperature. A number of experimental, analytical and computalional methods complement and support these studies.

A decision-tree analysis is presented for the evolution of corrosion damage. This considers

- Are environments and crevices present to induce localized corrosion? Consider conditions in moist layers of particulates and deposits.

- If Jocalized corrosion initiates, will it persist? Consider corrosion stifling and arrest as the process proceeds.

- What amount of metal penetration occurs? What is the size and distribution of corrosion sites?

- Based on these inputs, determine the evolution of corrosion damage over time.

It is important to consider the repository conditions (temperature-relative humidity) for various time-zones as they relate to the above. For example, a crucial time period for localized corrosion is defined between the following. When the drift walls are above boiling, a thermal barrier prevents water from dripping or seeping into the drifts. After the waste package surface has cooled below a critical temperature for localized corrosion, no further damage by this process will occur.

\section{Materials Performance Targeted Thrust of the Science and Technology Program}

An overview is presented of the Materials Performance targeted thrust of the U.S. Department of Energy/Office of Civilian Radioactive Waste Management's Office of Science and Technology and international. This thrust strives for increased scientific understanding, enhanced process models and advanced technologies for corrosion control.

- Corrosion processes on metal surfaces covered by moist particulate and deposits

- Evolution of corrosion damage by localized corrosion

- Evolution of the environment on melal surfaces

The focus is on processes of corrosion, materials science, electrochemistry, physical chemistry with coordinated, multi-investigator projects that engage leading scientists/engineers from Universities and National Laboratories. 